ELORE (ISSN 1456-3010), vol. $13-1 / 2006$.

Julkaisija: Suomen Kansantietouden Tutkijain Seura ry. Taitto: Jukka Talve. [http://cc.joensuu.fi/ oristi/1_06/fhm1_06.pdf]

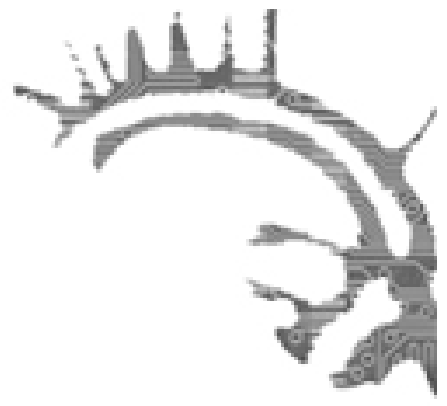

\title{
INTRODUCTION
}

Outi Fingerroos, Anne Heimo, Elina Makkonen

For some years now, folklorists and ethnologists interested in oral history research from different countries in Northern Europe have met at seminars, conferences and other scientific meetings, and discussed matters of mutual interest. It has been fascinating and academically stimulating to notice the differences in our research interests and methods in addition to the many similarities. In each country, oral history research is practiced according to different needs and aims, which derive from unique historical circumstances and disciplinary traditions. Meeting by meeting we realized how little we actually knew of what was happening in the field of oral history research in different countries. A major reason for this was that most of the studies were only published in native languages.

The first attempt to solve this problem was the founding of the Oral history research in the Nordic-Baltic area - a WebCT platform hosted by the Department of Estonian and Comparative Folklore, University of Tartu (< http://webct.e-uni.ee/ public/TUOHaLHRitNBA/index.html $>$ ) in autumn 2004. The platform provides a forum for researchers from all over to present and discuss matters related to oral history and life history research. In autumn 2005, researchers of oral history in Finland decided to start their own network: FOHN - Finnish Oral History Network. FOHN is currently organizing the international symposium Memory and Narration: Oral History Research in the Northern European Context to be held in Helsinki November 15-17 2006.

This theme issue of Elore is also the result of finding new ways to promote Nordic-Baltic oral history research for wider audiences. We are delighted that so many distinguished researchers whom we have met during the last few years accepted our invitation to write in this theme issue. Professor Vieda Skultans was the keynote speaker, together with Alessandro Portelli, at the international postgraduate seminar Methodological Choices in Oral History Research organized at the University of Turku in May 2004. We have had the pleasure of meeting Baiba Bela-Krūmiņa, Maija Hinkle and Māra Zirnìte several times at meetings and seminars organized by the Latvian 
National Oral History Project - NOH and its partners from different Nordic-Baltic countries. Tiiu Jaago is the administrator of the WebCT platform mentioned above and, like her colleagues from Estonia Ene Kõresaar and Aigi Rahi, works in the field of oral history and life stories. Katia Melnikova and Natalia Baschmakoff are our Russian partners. Individual members of FOHN are also well represented in this theme issue as authors and editors. As the articles, review articles and reviews show, there are various different ways of doing oral history research depending on each researcher's personal interests and scientific background.

\section{THE MANY FACES OF ORAL HISTORY}

This theme issue consists of articles and review articles on specific topics, and of reviews in which oral history research, projects and networks of different countries are presented. The first article in this volume is Doc. Tiiu Jaago's "What Actually Happened in Estonian Political and Narrated History", which concentrates on the oral history research from the point of view of different life stories in Estonia. Tiiu Jaago is a researcher of family tradition and oral history in the Estonian and Comparative Folklore at the University of Tartu. In her article, she examines the mutual relations of historical events and the oral and written narratives connected to them. She analyses stories of one event that took place in 1918 and its different descriptions and interpretations. Jaago aims to show that the narration of historical events has more to do with communication than the documentary description of historical events. Like Alessandro Portelli, Jaago shows that the past presented in the memories is a multilayered composition and not a clear or one-layered picture of the real events.

Phil. lic. Elina Makkonen is a researcher of Folklore from the Department of Finnish and Cultural Research at the University of Joensuu, Finland. In her article "Producing the Past Together: Group Interview and Oral History" Makkonen is concentrating on group interviews in the process of oral history research. She has done a lot of interviews and uses her own experiences in different interview situations as examples. She focuses on reminiscence talk and conversations and shows how narrators are negotiating about the memories with other narrators and the interviewer. In an interview situation an oral historian is piecing the past together with the narrators and Makkonen's aim is to show how important the different questions dealing with co-operation in the process of oral history research are. The central question of the article is: How is oral history produced?

BA Hons. (London), PhD (Wales) Vieda Skultans is a professor of Medical anthropology at the University of Bristol, United Kingdom and her work The Testimony of Lives. Narrative and Memory in Post-Soviet Latvia (published in 1998 by Routledge) is one of the most well known works on Latvian oral history abroad. Her article "Between

Experience and Text in Ethnography and Oral History" focuses on the number of relations between Ethnography, Anthropology and Oral History. Narratives and 


\section{Outi Fingerroos, Anne Heimo, Elina Makkonen}

memories require careful handling and Skultans's article seeks to address some of the basic problems that beset both oral historians and ethnographers as they seek to reconcile the dual allegiance to the experiential encounter and its textual transformation. In the article, Skultans hopes to identify what the theoretical and methodological issues that beset both Anthropology and Oral History can offer to each other and how they can, through dialogue, improve each other's shortcomings.

In the article "Sweet and Bitter Memories: Sweet and Bitter Memories: Reminiscence Talk - Statements, Descriptions, Narratives", Professor Natalia Baschmakoff, PhD, from the Department of Foreign Languages at the University of Joensuu, Finland, continues the discussion on spoken memories. The article is based on Baschmakoff's own experiences of interviewing Russian people, mainly the first wave émigrés and their children living in Finland but also the inhabitants of small Russian villages in the Pskov province, to which she has made several visits during a 10-year period, and the Karelian Isthmus where she has interviewed the summerdwellers. Like Makkonen, Baschmakoff also analyzes the researcher's or the researcherinterviewer's role when she uses reminiscence talk as a tool in the dialogue process.

PhD Baiba Bela-Krūmiņa has her background in studies of philosophy at the University of Latvia, where she started working as interviewer for the $\mathrm{NOH}-$ National Oral History project in the early 1990's. At the beginning of her review article "Research Opportunities of Life Stories: Everyday History" she explains her interest in the research of oral history, i.g. Latvian life stories - "personalities of narrators and events narrated excited me remarkably. I found Latvia's recent history not belonging only to history books and days of celebration or commemoration, but as real experience of people right beside me.” Bela-Krūmin, example of, and a short introduction to, the Latvian perception of the field of oral history. First, she discusses the appearance of the field and, secondly, she gives and analyses empirical examples of daily life aspects focusing on the historical experience of Latvian peasants in the time after World War II. Her analysis is based on the theory on change and adaptation.

PhD Maija Hinkle's review article "Latvian-Americans in the Post-Soviet Era: Cultural Factors on Return Migration in Oral History Interviews" examines the changing exile identity and the lack of return migration among Latvian-Americans to Latvia after it gained its independence in 1991, as revealed in the life narratives of individuals and in oral history workshops. Hinkle is the coordinator of the American Latvian Association (ALA) and leads the "Lifestory - Diaspora" project, which is a partner of the Latvian NOH - National Oral History project in the United States. The U.S. project works closely with "Lifestory" in Latvia in regard to its goals, methodology, and researchers. The main difference is that in the United States, the participants work independently, thousands of miles away from one another. Maija 
Hinkle's review article is based on the article "Latvian-American in the Post Soviet Era: Cultural Factors on Return Migration in Oral History Interviews", published in the international Journal of Baltic Studies volume 37 (Number 1) earlier this year.

$$
* * * * *
$$

This volume of Elore is related to international discussions dealing with oral history. Internationally, oral history and oral narratives are seen in many different ways. As the column written by Doc. Ulla-Maija Peltonen and all the texts in this issue show, there are various ways in which oral history is seen and conducted even in the Nordic and Baltic area. For example, in the Baltic countries, which have only recently become independent, the focus is on finding out the different interpretations of past that were silenced and prohibited earlier.

The aim of this theme issue is to present the oral history research in Northern Europe, particularly in Estonia, Latvia, Russia and Finland. We hope that the reader of this Elore's volume remembers to take into account the different historical and socio-economical backgrounds of the texts.

Dr. phil Outi Fingerroos is a Research Fellow (Academy of Finland) and works at the School of Cultural Production and Landscape Studies, University of Turku.

MA Anne Heimo is an assistant of Folklore Studies at the School of Cultural Studies, University of Turku.

Phil. lic. Elina Makkonen is a researcher of Folklore at the Department of Finnish and Cultural Research, University of Joensuu. 